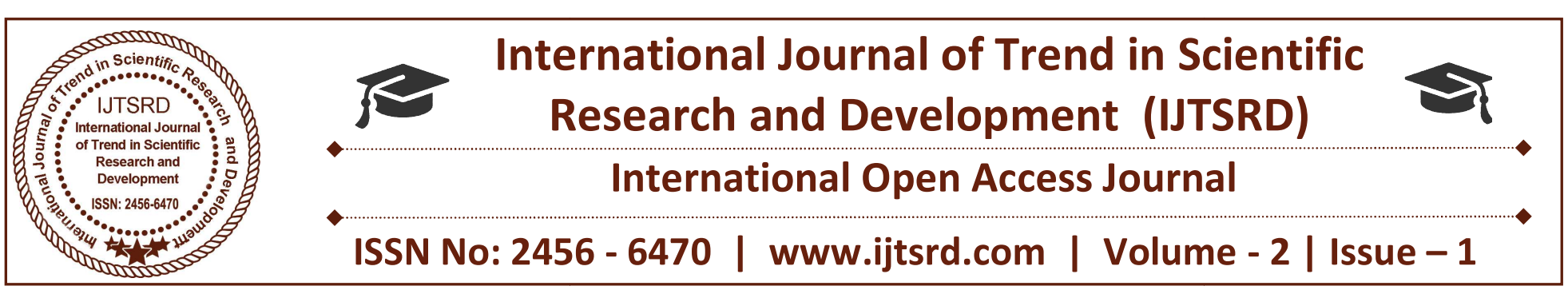

\title{
Customer Satisfaction towards Banking Services - A Study with Special Reference to Private Sector Banks in Erode District
}

\author{
Ms. D. Sivakami \\ M.Phil Research Scholar [Commerce], \\ K.S.Rangasamy College of Arts and Science \\ (Autonomous), Tiruchengode, Tamil Nadu, India
}

\author{
Dr. K. Vishvanathan \\ Associate Professor, Head and Department of \\ Commerce, K.S.Rangasamy College of Arts and \\ Science (Autonomous), Tiruchengode, Tamil Nadu
}

\begin{abstract}
Banks are part of the world of financial institutions, standing along investment banks, insurance companies, finance companies, investment managers and other companies that profit from the creation and flow of money. In current scenario the banking sector is an important financial institution. This study is much more helpful to banking industry for extent of their customer satisfaction by following various strategies which satisfying the need of the customers.
\end{abstract}

The respondents taken for this study is 220 and to measure the level of satisfaction garrets ranking tool has been used. This research has been conducted in order to critically evaluate and examine the customer satisfaction towards private sector banking service. This study leads to perform better in future.

Keywords: Bank, Customer, Customer Satisfaction, Private Sector Banks, Loans \& Advance, ATM

\section{INTRODUCTION TO THE STUDY}

Accounting for trillion in assets worldwide, the banking system is a crucial component of the global economy. While money-changing and money-lending may be as old as money, banking dates back to 15th century medieval Italy and played a major role in the rise of the Italian city-states as world economic powers. Ever since, the health of an economy and the health of its banks have been interrelated; the global credit crisis precipitated by the collapse of the subprime-fueled U.S. housing bubble is only the most recent example.
Banks are part of the world of financial institutions, standing along investment banks, insurance companies, finance companies, investment managers and other companies that profit from the creation and flow of money. As financial mediators, banks stand between depositors who supply capital and borrowers who demand capital. Given how much commerce and individual wealth rests on healthy banks, banks are also among the most heavily regulated businesses in the world.

\section{Meaning of Bank:}

The term bank has originated from the term 'Banchi'. In olden days, the traders of Italy who performed the job of exchanging money were known as Banchi or Bancheri because the table which they used for making payment was called as Banchi.

According to some people, the term bank is derived from the Greek word 'Banque.'

A bank deals in money in the same way as a businessman deals in goods. Banks are business enterprises which deal in money, financial instruments and provide financial services for a price called interest, discount, commission etc.

\section{Definitions of bank:}

"Banking is the business of accepting for the purpose of lending or investment, of deposits of money from the public repayable on demand or otherwise and 
withdraw-able by cheque, draft, and order or otherwise" - Indian Banking Regulation Act, 1949.

\section{Banking Worldwide}

Our history dates back to 1832 - the year when The Bank of Nova Scotia was founded. For the duration of the 19th century, and throughout the next, bank branches expanded across Canada, into the U.S. and overseas. In addition to its growing retail services, The Bank of Nova Scotia began providing corporate banking services from its New York offices in the early 80 's. By 1983, in response to increasing client demand, corporate banking services were offered in other U.S. cities and Canada.

In 1988, The Bank of Nova Scotia acquired McLeod Young Weir (later renamed Scotia McLeod Inc.) - a leading Toronto brokerage firm, founded in 1921. In November 1995, the wholesale arm of Scotia McLeod was formally integrated with the capital markets businesses of The Bank of Nova Scotia under the marketing banner Scotia Capital Markets. Complementing its combined capabilities, The Bank of Nova Scotia successfully acquired the long-standing leading dealer in bullion, The Mocatta Group, formed what is now known as ScotiaMocatta - the precious and base metals businesses of The Bank of Nova Scotia.

On November 1st, 1999, The Bank of Nova Scotia's Corporate Banking business and Scotia Capital Markets were integrated to form Scotia Capital - a marketing banner for the wholesale division of the bank and some of its subsidiaries.

In January 2012, to better reflect the growing international reach of the Corporate and Investment Banking and Capital Markets businesses, and to better align with the Bank's other business lines, the Scotia Capital brand name was discontinued, and the wholesale businesses are now branded as the Global Banking and Markets division of Scotia bank.

\section{Indian Banking System}

A healthy economy is achievable with a sound and effective banking system in India. The banking system of India should not only be hassle free but it should be able to meet new challenges posed by the technology and any other external and internal factors.

For the past three decades India's banking system has several outstanding achievements to its credit. The most striking is its extensive reach; it is no longer confined to only metropolitans or cosmopolitans in India. In fact, Indian banking system has reached even the remote comers of the country. This is one of the main reasons of India's growth process.

The government's regular policy for Indian bank since 1969 has paid rich dividends with the nationalization of 14 major private banks of India. Not long ago, an account holder had to wait for hours at the bank counters for getting a draft or for withdrawing his own money. Today, he has a choice, Gone are days when the most efficient bank transferred money from one branch to other in two days. Now it is simple as instant messaging or dials a pizza. Money has become the order of the day.

The first bank in India, though conservative, was established in 1786. From 1786 till today, the journey of Indian Banking System can be segregated into three distinct phases.

\section{NEW PRIVATE-SECTOR BANKS}

The banks, which came in operation after 1991, with the introduction of economic reforms and financial sector reforms are called "new private-sector banks". Banking regulation act was then amended in 1993, which permitted the entry of new private-sector banks in the Indian banking s sector. However, there were certain criteria set for the establishment of the new private-sector banks, some of those criteria being. The bank should have a minimum net worth of Rs. 200 crores. The promoters holding should be a minimum of $25 \%$ of the paid-up capital. Reliance Capital, India Post, Larsen \& Toubro, Shriram Transport Finance are companies pending in banking license with the RBI under the new policy, while IDFC \& Bandhan were given a go ahead to start banking services from 2015. Within 3 years of the starting of the operations, the bank should offer shares to public and their net worth must increased to 300 crores.

\section{CUSTOMER SATISFACTION}

Customer satisfaction is defined as the number of customers whose reported experience with its services (ratings) exceeds precise satisfaction goals. In an aggressive market place where businesses compete for customers, customer satisfaction is seen as a key differentiator and increasingly has become a key aspect of business strategy. At present gaining high levels of customer satisfaction is very important to a service provider institution like banking sectors. 
International Journal of Trend in Scientific Research and Development (IJTSRD) ISSN: 2456-6470

\section{OBJECTIVE}

$>$ To find out the level of satisfaction of customers towards the banking service offered by bank.

$>$ To find out the satisfaction level about the technology available in the bank.

\section{STATEMENT OF THE PROBLEM}

Today bank plays essential role for the customer services. Banking sector is an important ingredient of the country's economic liberalization; it has become urgent and pertinent for the banking industries in India to prepare itself to stand competition from the giant foreign banks. In order to retain and gain the existing Nowadays customers are more dynamic in their thinking. Their taste, needs and preferences keep changing as per the present situations. Therefore customer satisfaction is an important factor for capturing the market and also for retaining the existing ones. With this as the backdrop, the present study analyzes the level of satisfaction of the customers towards banking service and factors that influence the customers

Below questions contains a general problem written in the form of statement followed by the specific questions:

- How does the demographic profile influence the customer satisfaction and banking service?

- What is the relationship among customer perception and bankers attitude?

\section{RESEARCH METHODOLOGY}

This is an analytical study based mainly on the primary data collected through scientifically developed questionnaire method. The questionnaire was personally administered on a sample size of 220, chosen on a simple random basis among four private sector bank customers in the city of Erode. The sample size of 220 is divided equally from five private sector banks. Thirty customers represent each bank. ICICI bank, Karurvysa bank, Lakshmivilas bank and HDFC bank represent the private sector banks. In order to study the customers satisfaction towards the services provided by private banks, a pre tested questionnaire was administrated and their opinion regarding various attributes contributing satisfaction to customers were collected.

In order to measure the level of satisfaction 3 statements were administered to the respondents. The statements were so designed to assess their satisfaction on various aspects, namely Accessibility, Sufficient space, Grievance redresses, Opening an account, withdrawal, depositing money, convenient working hours, Modern Banking Services, Availability / Working of ATMs, Speed of Processing and distribution of loans, Collection charges for cheque / Overdraft Draft, Interest rate.

Population: Private Banks in Erode city.

Sample: Sample covers the respondents of 4 private banks alone.

Sample Size: The sample size of 220 respondents.

\section{DATA COLLECTION METHOD}

\section{Questionnaire}

The primary data has been collected through a wellstructured questionnaire.

In our study the main emphasis was on the questionnaire method. Question, which was asked, were of multiple choices in nature and were of, closed end.

\section{Personal Interview}

Personal interview were also conducted. There was face to face conversation between researcher and the respondents. All the answers were recorded while interview was in progress. Through interviewing, additional information was received regarding our study.

\section{LIMITATIONS OF THE STUDY}

Banks are selected only from erode district.

The survey was carried through questionnaire and the questions were based on banking service.

$>$ Some of the respondents of the survey were unwilling to share information's like income.

Private sector banks only selected.

\section{REVIEW OF LITRATURE}

Mesay Sata Shanka (2012) in his article "Bank Service Quality, Customer Satisfaction and Loyalty in Ethiopian Banking Sector". He measures the service quality offered by private banks in Ethiopian. The relationship between the service quality and customer satisfaction and loyalty.

The research finding indicates offering high quality service increase customer satisfaction, which leads to high level of customer commitment and loyalty. Although this research provides some significant 
insights into service quality in Ethiopian banking industry.

R.Arumugarajan (2016) in his article "A Comparative Study on the Customers' Satisfaction in Select Private Sector and Public Sector Banks in Tirunelveli District". Studied due to privatization, many of the private party also enter in to banking sector. Thus, the customers have different kinds of banks. So the satisfaction level of customers has very vital role among the banks. Hence he concludes that private and foreign sector banks are quite successful in providing their customers with what they want, when they want and where they want. But public sector banks are still lagging behind their counterparts in these aspects.

Aseem Mathur (2014) in his article "Customer's Trends towards Public and Private Sector Banks". Now 'Anywhere Banking' and 'Anytime Banking' has turn into a reality. Banking activities have increased enormously with a clear change in way of life and techniques especially in the field of lending, from wholesale to retail character. Now, customer is the input component of banking industry. Banking Industry can neither function without customers nor is just acquiring a definite number of customers adequate for their business. Finally he conclude that 10 most important factors influencing the selection of a bank they are safety of funds, secured ATMs, ATMs availability, reputation of the bank etc., On the other hand, "Advertisements" was not ranked important. Banks do not need to spend much amount on the part of advertisements.

Dwayne D.Gremler and Stephen W. Brown (1996) in their article "Service Loyalty: Its Nature, Importance, and Implications". Service organizations are frequently looking for ways to boost customer loyalty. He examines service loyalty and factors affecting its development. Satisfaction, switching costs, and interpersonal bonds are proposed as model of service loyalty. The "bonding" that frequently occurs in customer-service provider employee relationships are conceptualized as the construct interpersonal bonds.

Dr Manasa Nagabhushanam in his study "A Study on Customer Service Quality of Bank in India". In her research banking industry facing certain challenges (i.e.) challenges of quality service, customer satisfaction, customer retention, customer loyalty, quality service plays a major role in achieving customer satisfaction. Each bank is having their way of services. Service is intangible in nature which could not be compared due to this differentiation. At last she concludes that banking sector today has a compelling demand for improvement to sustain their customer. It is advisable that the public sector bank associate with technology and good infrastructure. Foreign bank try to concentrate on net worth individuals.

Ramya T J (2016) in her study "A Study on Customer Satisfaction towards Private Banks with special reference to Mysuru City" The banking industry has an incredible growth in Indian market. The doorway of new technology has made lot of changes in Indian banking sector. Newly the Indian economy has seen the emergency of many banks in the private sector. The growth of private bank is not possible without achieving customer satisfaction. Customer satisfaction is a present-day come within reach of to survive in the market .Gauging of customer satisfaction is currently very central to gain self-assurance to build the market. The study indicates service and employee commitment is very important for customer satisfaction.

\section{ANALYSIS AND DISCUSSION}

\section{GATTER'S RANKING}

Garrets Ranking Technique has been used to investigate the facilities provided by the bank the respondents. Garrett's ranking technique was used to rank the preference indicated by the respondents on different factors. As per this method, respondents have been asked to assign the rank for all factors and the outcomes of such ranking have been converted into score value with the help of the following formula:

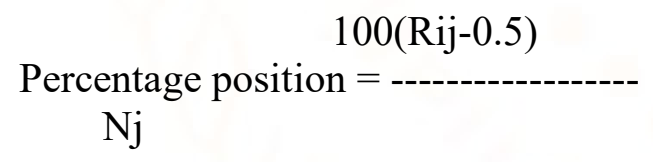

Where Rij = Rank given for $i$ th variable by the $j$ th respondent. $\mathrm{Nj}=$ Number of variables ranked by the

\section{OPINION OF THE RESPONDENTS ABOUT BANKING FACILITIES}

The respondents were asked to rank the six facilities that identified for the purpose of this study as $1,2,3$, 4,5and, 6 in order to know their preferences. The calculated percentage positions for the ranks 1, 2,3,4,5, and, 6 and their corresponding Garrett's table values. 
International Journal of Trend in Scientific Research and Development (IJTSRD) ISSN: 2456-6470

Percentage position and their corresponding Garrett's table values

\begin{tabular}{|l|l|l|l|}
\hline Rank & $\begin{array}{l}\text { Percentage } \\
\text { Position }\end{array}$ & Percentage & $\begin{array}{l}\text { Garrett's } \\
\text { table value }\end{array}$ \\
\hline 1 & $100(1-0.5) 6$ & 8.33 & 77 \\
\hline 2 & $100(2-0.5) 6$ & 25 & 63 \\
\hline 3 & $100(3-0.5) 6$ & 41.67 & 54 \\
\hline 4 & $100(4-0.5) 6$ & 58.33 & 46 \\
\hline 5 & $100(5-0.5) 6$ & 75 & 37 \\
\hline 6 & $100(6-0.5) 6$ & 91.67 & 23 \\
\hline
\end{tabular}

From the above table it shows that the percentage positions for the ranks $1,2,3,4,5$, and 6 and their corresponding Garrets table values.
For Rank 1, the calculated percentage position is 8.33 the table value is 77 . This value is given in the Garrets ranking table for the percentage of 8.33. For Rank 2, the calculated percentage position is 25 the table value is 48 . This value is given in the Garrets ranking table for the percentage of 25.48 , which is very near to 25 . For Rank 3, the calculated percentage position is 41.97 the table value is 54 . This value is given in the Garrets ranking table for the percentage of 41.67. For Rank 4, the calculated percentage position is 58.33 the table value is 46 . This value is given in the Garrets ranking table for the percentage of 58.03, which is very near to 58.33. For Rank 5, the calculated percentage position is 75 the table value is 37 . This value is given in the Garrets ranking table for the percentage of 74.52, which is very near to 75 . For Rank 6, the calculated percentage position is 91.67 the table value is 23 . This value is given in the Garrets ranking table for the percentage of 91

TABLE-I

OPINION OF THE RESPONDENTS ABOUT BANKING FACILITIES

\begin{tabular}{|c|c|c|c|c|c|c|c|c|c|c|c|}
\hline \multirow[t]{2}{*}{ S. No. } & \multirow[t]{2}{*}{ Service } & \multicolumn{6}{|c|}{ Rank } & \multirow{2}{*}{$\begin{array}{l}\text { Total no. of } \\
\text { respondents }\end{array}$} & \multirow{2}{*}{$\begin{array}{l}\text { Total } \\
\text { score }\end{array}$} & \multirow{2}{*}{$\begin{array}{l}\text { Mean } \\
\text { score }\end{array}$} & \multirow[t]{2}{*}{ Rank } \\
\hline & & 1 & 2 & 3 & 4 & 5 & 6 & & & & \\
\hline 1 & $\begin{array}{l}\text { Loans } \\
\text { advance }\end{array}$ & 22 & 34 & 45 & 51 & 33 & 35 & 220 & 10876 & 49.44 & VI \\
\hline 2 & Credit card & 44 & 33 & 44 & 43 & 44 & 12 & 220 & 11956 & 54.35 & II \\
\hline 3 & Debit card & 36 & 10 & 55 & 65 & 43 & 11 & 220 & 11276 & 51.25 & IV \\
\hline 4 & Internet banking & 10 & 73 & 50 & 21 & 44 & 22 & 220 & 11680 & 53.09 & III \\
\hline 5 & Mobile banking & 62 & 46 & 12 & 32 & 35 & 33 & 220 & 12168 & 55.31 & I \\
\hline 6 & NEFT & 52 & 22 & 39 & 28 & 32 & 47 & 220 & 11203 & 50.92 & $\mathrm{~V}$ \\
\hline
\end{tabular}

Source: Primary Data

From the above table it shows that the number of respondents ranking the banking facilities as $1,2,3,4,5$ and 6 . This table also shows the total score and the mean score.

For factor banking facility the total score is calculated by multiplying the number of respondents ranking that factor as $1,2,3,4,5$ and 6 by their respective table values given in Table I. Mean score is calculated by dividing the total score by the number of respondents. It is seen from Table II that according to the Garrett ranking, the mean score of 49.44, 54.35, 51.25, 53.09, 55.31 and 50.92 is allotted to loans and advances, Credit Card, debit card, internet banking, mobile banking and NEFT respectively. To conclude, the banking facilities which satisfy to the respondents are in this order namely Mobile banking, Credit card, Internet banking, Debit card, NEFT and Loans \& advance.

\section{OPINION OF THE RESPONDENTS ABOUT AVAILABILITY OF SERVICES DURING DEMONETIZATION}

The respondents were asked to rank the six factors identified for the purpose of this study as $1,2,3,4,5$ and 6 in order to know their opinion about availability of services during demonetization. The calculated percentage positions for the ranks 1,2,3,4 and 5 their corresponding Garrett's table values are given in following table. 
International Journal of Trend in Scientific Research and Development (IJTSRD) ISSN: 2456-6470

Percentage position and their corresponding garret's table values

\begin{tabular}{|l|l|l|l|}
\hline Rank & $\begin{array}{l}\text { Percentage } \\
\text { Position }\end{array}$ & Percentage & $\begin{array}{l}\text { Garrett's } \\
\text { table value }\end{array}$ \\
\hline 1 & $100(1-0.5) / 5$ & 10 & 75 \\
\hline 2 & $100(2-0.5) / 5$ & 30 & 61 \\
\hline 3 & $100(3-0.5) / 5$ & 50 & 50 \\
\hline 4 & $100(4-0.5) / 5$ & 70 & 40 \\
\hline 5 & $100(5-0.5) / 5$ & 90 & 25 \\
\hline
\end{tabular}

The above table shows the percentage positions for the ranks1, 2, 3, 4, and 5 and their corresponding Garrets table values.
For Rank 1, the calculated percentage position is 10 the table value is 75 . This value is given in the Garrets ranking table for the percentage 10.16 , which is very near to 10. For Rank 2, the calculated percentage position is 30 the table value is 61 . This value is given in the Garrets ranking table for the percentage 28.86, which is very near to 30 . For Rank 3 , the calculated percentage position is 50 the table value is 50 . This value is given in the Garrets ranking table for the percentage 50. For Rank 4, the calculated percentage position is 70 the table value is 40 . This value is given in the Garrets ranking table for the percentage 69.39, which is very near to 70 . For Rank 5 , the calculated percentage position is 90 the table value is 25 . This value is given in the Garrets ranking table for the percentage 89.94 , which is very near to 90 .

TABLE-II

OPINION OF THE RESPONDENTS ABOUT AVAILABILITY OF SERVICES DURING DEMONETIZATION

\begin{tabular}{|c|c|c|c|c|c|c|c|c|c|c|}
\hline \multirow[t]{2}{*}{ S.No. } & \multirow{2}{*}{$\begin{array}{l}\text { Availability of } \\
\text { Service }\end{array}$} & \multicolumn{5}{|c|}{ Rank } & \multirow{2}{*}{$\begin{array}{l}\text { Total no. of } \\
\text { respondents }\end{array}$} & \multirow{2}{*}{$\begin{array}{l}\text { Total } \\
\text { score }\end{array}$} & \multirow{2}{*}{$\begin{array}{l}\text { Mean } \\
\text { score }\end{array}$} & \multirow[t]{2}{*}{ Rank } \\
\hline & & 1 & 2 & 3 & 4 & 5 & & & & \\
\hline 1 & Refilling ATM & 74 & 37 & 36 & 36 & 37 & 220 & 11972 & 54.42 & I \\
\hline 2 & $\begin{array}{l}\text { Availability of } \\
\text { cash in bank }\end{array}$ & 18 & 20 & 80 & 68 & 34 & 220 & 10140 & 46.09 & $\mathrm{~V}$ \\
\hline 3 & Working time & 35 & 40 & 61 & 45 & 39 & 220 & 10890 & 49.50 & IV \\
\hline 4 & $\begin{array}{l}\text { Time duration } \\
\text { for transaction }\end{array}$ & 60 & 60 & 24 & 25 & 51 & 220 & 11635 & 52.89 & II \\
\hline 5 & $\begin{array}{l}\text { Electronic } \\
\text { transfers }\end{array}$ & 47 & 60 & 13 & 40 & 60 & 220 & 10935 & 49.71 & III \\
\hline
\end{tabular}

Source: Primary Data

Table II shows the number of respondents ranking the factors banking facilities as $1,2,3,4$, and 5 . This table also shows the total score and the mean score.

For factor service provided by bank the total score is calculated by multiplying the number of respondents ranking that factor as $1,2,3,4$ and 5 by their respective table values given in Table II. Mean score is calculated by dividing the total score by the number of respondents. It is seen from Table II that according to the Garrett ranking, the factors which induces the respondents to show availability of service are in this order namely Refilling ATM, Availability of cash in bank, Working time, Time duration for transaction, Electronic transfers. It is seen from Table II that according to the Garrett ranking, the mean score of $54.42,46.09,49.50,52.89$ and 49.71 is allotted to
Refilling ATM, Availability of cash in bank, working time, time duration for transaction and Electronic transfers respectively.

\section{CONCLUSON}

In a country like India, there is demand for providing better service to their customer. Banks must be able to satisfy their customer by their service in order to retain the customers from vary area. The present study shows that customers are more enthusiastic to join new technologies or methods that might contain little risk. Banks should ensure that the modern banking service is safe and secure for financial transaction compare with traditional banking. So, it is concluded that overall service provided by the bank satisfies the customers. And it helps to retain their customers. 


\section{REFERENCE}

1. Ali, K "Banks In Equity Market - A Risk Analysis". Journal of Management and Science , 2 (1), 23-31.

2. DR. K.alagarsamy, S. (2013). "A Study on Customer Behavior towards Banking Services with Special Reference to Public Sector Banks in Sivagangai Dist". Asia Pacific Journal of Marketing \& Management Review , 2 (2), 183-196.

3. Dr.A.Vennila MBA, M. (2014). "Problems Faced By The Customers With Reference to E-Banking Services in Private Sector Banks" . International Journal of World Research , 1 (11), 44-47.

4. Dr.T.Vijayaragavan. ( 2014). "Modern Banking Services - A key Tool for Banking Sector". IRACST - International Journal of Commerce, Business and Management (IJCBM) , 3 (4), 589594.

5. Felix, R. (2017). "Service Quality and Customer Satisfaction in Selected Banks in Rwanda". Journal of Business and Financial Affairs , 6 (1), 1-11.

6. Gabcova, J. B. (2014). "Reasons for Satisfaction and Dissatisfaction of Bank Customers". Study from Slovakia and The Czech Republic". International Journal of Entrepreneurial Knowledge , 2 (1), 4-13.
7. George, B. (2015). "Recent Trends in Banking Sector Challenges and Opportunities". International Journal of Current Research , 7 (10), 21913-21915.

8. Mei Mei Lau et al. (2013). "Measuring Service Quality in the Banking Industry": A Hong Kong Based Study. Contemporary Management Research , 9 (3), 263-282.

9. Mwatsika, C. ( 2016). "Impact of ATM Banking Performance on Customer". International Journal of Business and Economics Research, 5 (1), 1-9.

10. Sharma, D. J. (2017). "A Study on Innovation in Banking and its Impact on Customer Satisfaction". IOSR Journal of Economics and Finance (IOSRJEF) , 70-74.

11. Tariq Khalil Bharwana, D. M. (2013). "Impact of service quality of customer's satisfaction: A study from service sector especially private college of isalabad, Punjab, Pakistan Faisalabad". International Journal of Scientific and Research Publications , 3 (5), 1-7.

12. TIWARI, R. (2012). "Information Technology in Banking Sector". Asia Pacific Journal Of Marketing And Management Review , 1 (1), 1-9.

13. MOHANRAJ, M. (2017). "A Study on Customer Attitude towards Mobile Banking with Special Reference to Erode District". International Journal of Trend in Scientific Research and Development (IJTSRD), 2 (1), 258-263. 